Self review

\title{
Regulatory effects of terahertz waves
}

\author{
Vyacheslav F. Kirichuk, Alexey N. Ivanov
}

Saratov State Medical University n.a. V.I. Razumovsky, Saratov, Russia

Received 30 May 2013, Accepted 20 September 2013

(C) 2013, Kirichuk V.F., Ivanov A.N.

(C) 2013, Russian Open Medical Journal

Abstract: There are modern data about biological effects of terahertz (THz) waves in this article. Items of interaction of THz waves with bio objects of different organization level. A complex of the data indicates that the realization of a THz wave effect in biosystems is possible at molecular, cellular, tissular, organ and system levels of regulation. There are data about changes in nervous and humoral regulation of an organism and metabolic effects of $\mathrm{THz}$ waves.

Keywords: terahertz waves, regulation

Cite as Kirichuk VF, Ivanov AN. Regulatory effects of terahertz waves. Russian Open Medical Journal 2013; 2: 0402.

Correspondence to Prof. Vyacheslav F. Kirichuk. Address: Department of normal physiology n.a. I.A. Chuevsky, Saratov State Medical University n.a. V.I. Razumovsky, 112, Bolshaya Kazachiya str., Saratov, 410012, Russia. E-mail: normalf@yandex.ru

Radionics progress and its adoption to all spheres of science, techniques and everyday life is an essential part of civilization [13]. Among an amount of environmental factors causing significant changes in a functional condition of biological systems of different organization levels, the main role belongs to electromagnetic irradiations (EMI) [4, 5].

Terahertz (THz) therapy is a relatively new, but rather advanced physiotherapeutic method of treatment [6-8]. Biological effects of $\mathrm{THz}$ radiation are registered at an irradiation power flux density significantly lower than $10 \mathrm{~mW} / \mathrm{cm}^{2}$. At such a low intensity an integrated heating of irradiated objects in the experiment is no more than $0.1^{\circ} \mathrm{C}$. That is why $\mathrm{THz}$ electromagnetic radiation is classified as informational, nonthermal exposures [9].

A feature of terahertz waves to expose bioobjects is characterized by locating in this band of its fundamental frequencies of vibrational-rotational transitions of water and biological molecules (prime and composite), as well as big polymers (polypeptides, proteins) [10]. It is known that molecular emission and absorption spectra (MEAS) of many bioactive substances (nitrogen oxide - NO, carbon oxide - $\mathrm{CO}$, molecular oxygen and its active forms, etc.) are in $\mathrm{THz}$ band $[11,12]$. Besides, in submillimeter part of $\mathrm{THz}$ band, according to theoretical calculations and measurements, there are fundamental frequencies of membrane, intracellular machinery and cells vibrations. This may cause resonance effects at a coincidence with frequencies of external electromagnetic irradiation [13].

\section{Biological effects of terahertz waves at a molecular level}

A significant effect of this irradiation on biopolymers condition had been experimentally proved. During the $\mathrm{THz}$ irradiation of albumin protein samples there had been revealed conformational transitions of these macromolecules. These transitions had been registered by different spectroscopic methods, which let fix changes in correlation fractions of condensed and folded structures, and changes in optical albumin density in absorption area of peptid and disulfide bonds [14-17]. This indicates that $\mathrm{THz}$ irradiation induces conformational change in albumin molecules caused by the change in its bonding property. This fact is confirmed by the study of persistent $\mathrm{THz}$ irradiation influence of $3.68 \mathrm{THz}$ frequency on bonding albumin with progesterone, which is performed by hydrophobic interaction of bonding centers with rests of triptophane, tyrosine, arginine and lysine. It had been showed that albumin bonding property, irradiated by $\mathrm{THz}$ waves, increases $[14,18]$.

Today a dynamics of change in the level of antioxidant enzymes: superoxide dismutase of aurococcus, catalase, peroxidase, collibacillus and blue pus organism under the influence of $\mathrm{THz}$ electromagnetic waves of MEAS of atmospheric oxygen (129 GHz) and MEAS of nitrogen oxide (150.176-150.664 GHz). It had been revealed an increase of antioxidant enzymes potency of radiated organisms races, the most evident at 45-minute exsposition of $\mathrm{THz}$ waves of $129 \mathrm{GHz}$, and at 45- and 60-minute expositions of $\mathrm{THz}$ waves of $150.176-150.664 \mathrm{GHz}$ [19-21]. It had been also fixed that $\mathrm{THz}$ waves of $150.176-150.664 \mathrm{GHz}$ cause a recovery of normal superoxide dismutase and catalase potency of erythrocytes in white rats under the acute immobilization stress condition [22]. Change in intermolecular protein interactions under the $\mathrm{THz}$ waves irradiation had been demonstrated by the example of change in stability of antigen-antibody complex under the electromagnetic waves irradiation of $100 \mathrm{GHz}$ [23]. So one of the significant molecular mechanisms of $\mathrm{THz}$ waves is a change in enzymes and enzymatic systems in cells. 


\section{Subcellular level of effects realization of $\mathrm{THz}$ waves}

$\mathrm{THz}$ waves influence cell membranes. So in the experiments of the study of $\mathrm{THz}$ waves effect on osmolar resistance of erythrocytes in mice, and it had been showed that electromagnetic irradiation of $3.68 \mathrm{THz}$ increases a low cell membrane resistance [24]. It had been found out an influence of $\mathrm{THz}$ (submillimeter) irradiation on processes of transmembrane traffic in neurons. Set of experiments with the use of a coloring material which does not penetrate through intact membranes (Trypan Blue), and reveals living cell, and electrophysiological analyze showed that $\mathrm{THz}$ irradiation creates conditions for penetrating of those substances into living cells, which do not usually penetrate [25]. Besides, it had been established that penetrance of phospholipid liposomes increases significantly after $130 \mathrm{GHz}$ irradiation with density $10-17 \mathrm{~mW} / \mathrm{cm}^{2}$ [26].

Thus, mechanisms of molecular and subsellular levels take part in effects realization of $\mathrm{THz}$ waves. Change in enzymatic systems activity and cell membrane properties are typical to $\mathrm{THz}$ irradiation as well as to waves of other bands.

\section{Cellular level of effects realization of $\mathrm{THz}$ waves}

There is an amount of descriptions of the cellular effects of $\mathrm{THz}$ irradiation in medical literature. So it had been established that $\mathrm{THz}$ irradiation of $3.68 \mathrm{THz}$ intensifies spontaneous and mainly induced mitoses of human lymphocytes. It had been displayed that $\mathrm{THz}$ waves have differently directed effect in lymphocytes population and the cell reaction on the irradiation depends on its functional condition [24]. Moreover, $\mathrm{THz}$ waves influence also intercellular interactions. So, it had been fixed that thrombocytes incubation in the patients with unstable angina with blood platelets, irradiated by $\mathrm{THz}$ waves of $150.176-150.664 \mathrm{GHz}$ of NO, causes a decrease of activity [27].

Besides, it had been displayed that incubation in the system irradiated by the given waves and non-irradiated blood of the patients with unstable angina causes a reliable increase of a blood viscosity [28]. We had fixed that mitotic activity of irradiated lymphocytes $(3.68 \mathrm{THz})$ is higher in the presence of irradiated monocytes then at a contact with non-irradiated monocytes [15]. Effect of $\mathrm{THz}$ waves on monocyte-macrophage system is realized not only by the effect on regulatory monocyte function, but also by macrophage phagocytic activity. We had demonstrated that $\mathrm{THz}$ irradiation of $150.176-150.664 \mathrm{GHz}$ of $\mathrm{NO}$ exposure on peritoneal macrophage increases extremely their phagocytic activity. This is evident as from an increase of the percent of cells taking part in a phagocytosis process (phagocytic index) as from an increase of bacterial cells numbe occupated by one macrophage (phagocytic number) [29].

Erythrocytes, causing blood viscosity properties, are sensitive evidently to $\mathrm{THz}$ irradiation at in vitro conditions. In the study of N.V. Mamontova [30] there had been established the fact of a normalization of defected blood viscosity properties, erythrocytes aggregation and deformability in the patients with unstable angina under the natural electromagnetic field of EMI on $240 \mathrm{GHz}$ (the most evident at 15-minute irradiation mode). There had also been demonstrated a statistically valid normalization of blood viscosity properties, erythrocytes aggregation and deformability in the patients with unstable angina in crossed magnetic and electric fields under $240 \mathrm{GHz}$ EMI (the most evident at 15-minute irradiation mode) [30]. The authors had also denoted that 30 minutes is an interaction time of EMI with terahertz frequencies (THF) $(240 \mathrm{GHz})$ normalizing effect influences blood viscosity properties, erythrocytes aggregation and deformability in the patients with unstable angina at in vitro conditions [30].

A.P. Krenitckiy, A.V. Maiborodin, V.D. Tupikin et al. [31] had showed normalization of thrombocyte functional activity in the patients with unstable angina under EMI of NO THF $(240 \mathrm{GHz})$, which was accompanied by statistically valid decrease of a maximal size of appearing thrombocytic aggregates, maximal speed of the most thrombocytic aggregates appearing, maximal aggregation degree [31] (at in vitro conditions).

We [32] had also displayed that at EMI of NO THF (400 GHz) enriched by thrombocytes of the patients with unstable angina plasma (at in vitro conditions), there was a significant decrease of blood platelets aggregability, which had been accompanied by statistically valid decrease of a maximal size of appearing thrombocytic aggregates, maximal speed and aggregation degree.

It had been revealed a significant effect of $\mathrm{THz}$ waves on neurons at in vitro conditions. In a pond snail (Lymnaea stagnalis) isolated neurons the most evident effect of $\mathrm{THz}$ irradiation of 0.7 , 2.49 and $3.69 \mathrm{THz}$ was on cells growth, their adhesion, membrane morphology change and intercellular structures, and the value of membrane resting potential. As a result, we can see that $\mathrm{THz}$ waves significantly influence morpho-functional neurons condition, this predetermines a realization of effects in nervous system [33-35].

Thus, the given data indicate that the mechanism of $\mathrm{THz}$ waves can be realized at a cellular level. Change in regulatory mechanisms of molecular, subcellular and cellular levels will lead to realization of influence on functional condition of tissues, organs and a whole organism.

$\mathrm{THz}$ waves effect on nervous and humoral regulating functions of an organism

Studies in $\mathrm{THz}$ waves influence on cells, tissues, organs and organ systems generate a significant interest (at in vitro conditions). First, it should be noted changes in nervous and humoral regulating functions under $\mathrm{THz}$ irradiation. So, it had been denoted that $\mathrm{THz}$ waves can influence the central nervous system and the higher nervous activity of animals. It had been indicated that a high power $\mathrm{THz}$ irradiation (60-minutes) of MEAS of NO $(150.176-150.664 \mathrm{GHz})$ in male rats under the acute immobilization stress, leads to a depression of a motion activity. This was evident from a statistically valid increase of a total time that animals had spent in Small Labyrinth, and a total time of animals' washing process $[36,37]$.

Experimental studying display that $\mathrm{THz}$ waves of different frequencies can cause various changes in behavioral reactions. It had been established that male rats which had got a 5-day long low-intensity waves of $167 \mathrm{GHz}$, kept normal searching reactions, curiosity, active positive communication, as irradiated animals of the same length and power of $144 \mathrm{GHz}$ had an anxious behavior, reduced appetite and sleep time, displayed aggression [38].

With the help of experiments on laboratory mice it had been fixed that $3.68 \mathrm{THz}$ irradiation causes reaction of avoiding, displacement of a motion activity and state anxiety which do not disappear on the next day of irradiation [39].

The results given below display that $\mathrm{THz}$ irradiation have a significant effect on behavioral reactions, and, as a result, on the central nervous system and the higher nervous activity of animals. A variety of effects of $\mathrm{THz}$ irradiation depending of a frequency comes under notice. 
There are data about $\mathrm{THz}$ irradiation effect on humoral regulating function of an organism. There had been showed that at a 5-day long $\mathrm{THz}$ irradiation with NO frequencies (150.176$150.664 \mathrm{GHz}$ ) (30 minute), a total normalization of defected functional activity of thyroid body was denoted in male rats. At the same time the concentration of free and bonded thyroxin and triiodothyronine fractions, thyroglobulin concentration, proportion $\mathrm{T}_{3} / \mathrm{T}_{4}$ and thyreotrophin had been normalized and statistically valid had not differ from the control group. The presented indices indicate that at the given irradiation there is a total normalization of thyroid body activity $[40,41]$.

It had been established that $\mathrm{THz}$ waves have different effects on adrenal body condition in rats under stress depending on a frequency. Irradiating of rats with a 5-day 15-minute exposition of $167 \mathrm{GHz}$ after 3-hour immobilization prevents hypertrophia of adrenal body in stress and typical histological change developing. The same exposition but of $144 \mathrm{GHz}$ increases morphological changes in adrenal body in stress [42]. It had been showed that $\mathrm{THz}$ irradiation of MEAS of $129 \mathrm{GHz}$ atmospheric oxygen stimulates a decrease of corticosterone concentration in male rats under acute and prolonged stress. Single-shot persistent 15-minute irradiation of $\mathrm{THz}$ band of the given frequency (on the background of acute immobilization stress) totally normalizes defected corticosterone concentration in experimental animals. The most effective irradiation time mode at the prolonged stress is a 5-day 30-minute exposition of $150.176-150.664 \mathrm{GHz}$ of NO can prevent corticotrophin expulsion in white rats at immobilization stress [45].

Thus, the effect of $\mathrm{THz}$ waves can change as nervous as humoral regulating mechanism in an organism.

\section{Metabolic effects of THz waves}

Experimental research displays that $\mathrm{THz}$ waves have a variety of metabolic effects. It had been demonstrated a possibility of metabolic status correction (carbon, lipid and protein balance) with the use of EMI of $150.176-150.664 \mathrm{GHz}$ of NO of male rats under the acute immobilization stress. A 5-day 15-minute exposition of the same frequency can effectively reduce a high triglycerids concentration in animals' blood. Time mode increasing of exposition up to 30 minutes normalizes glucose and triglycerids level in blood.

A 30-minute exposition of electromagnetic waves corrects glucose, creatinine and urea in blood serum in rats under prolonged immobilization stress [46].

There had also been fixed normalization of protein metabolism in an organism. A 30-minute exposition of electromagnetic waves $150.176-150.664 \mathrm{GHz}$ of NO rats under acute stress causes normalization a protein concentration in blood plasma, recovery of a proportion of protein fractions: albumin level increases, percentage concentration of protein of globulin fraction significantly decreases. There is a decrease of high concentrations of $\alpha 1-, \alpha 2$ - and $\beta$ - globulins comparing with non-irradiated animals under acute stress [47].

Besides, there had been fixed a normalizing effect of $\mathrm{THz}$ waves $150.176-150.664 \mathrm{GHz}$ (NO) on activity of plasma enzymes in rats under prolonged immobilization stress. So at this irradiation there is a normalization of changed transaminase, glutathione-Stransferase, lactic dehydrogenase activity and ceruloplasmin in blood plasma $[46,47]$.

Lipid peroxidation (LPO) has a significant value among metabolic effects of $\mathrm{THz}$ irradiation. It is known that defects in LPO processes are one of common pathogenesis mechanisms of variable diseases, cardiovascular failures as well [48]. It had been indicated that $\mathrm{THz}$ waves $150.176-150.664 \mathrm{GHz}$ of $\mathrm{NO}$ cause toxical lipid peroxidation intermediate products (lipid hydroperoxides, malondialdehyde) in blood serum and erythrocytes, and cytolysis and autointoxication markers (molecules of an average mass) in rats' blood under acute immobilization stress. A decrease of molecules of an average mass level in a blood serum under acute immobilization stress at the $\mathrm{THz}$ waves exposure indicates a decrease of an autointoxication degree and reduce of cytolysis syndrome [49].

An oxidoreduction balance in an organism is tightly connected with a blood gas recovery. It had been fixed that at the $\mathrm{THz}$ waves 150.176-150.664 GHz of NO there was an increase of a partial pressure of arterial oxygen in male rats under acute and prolonged immobilization stress $[50,51]$.

Thus, electromagnetic waves of $\mathrm{THz}$ band influence significantly the mechanisms of nervous and endocrine control and metabolic status in a whole organism.

\section{THz waves effects on different organs and organ systems} condition

Over the last years there have been new data appeared about an effect of $\mathrm{THz}$ waves of different frequencies on a structure of some tissues, organs and systems. In particular it had been indicated an effect of $\mathrm{THz}$ waves of $150.176-150.664 \mathrm{GHz}$ on cartilaginous tissues condition in white rats under acute and prolonged immobilization stress. In experimental animals under $\mathrm{THz}$ waves of $150.176-150.664 \mathrm{GHz}$ on the background of acute and prolonged immobilization stress, there was a decrease of dilatation and color variations of collagen fibers in cartilaginous tissues, normalization of its homogeneity, seldom episodes of vacuolization and chondrocyte karyopyknosis [52].

It had been revealed an effect of $\mathrm{THz}$ waves of $167 \mathrm{GHz}$ and $144 \mathrm{GHz}$ on structure-functional change in renal of male rats under stress condition. The results of the experiment indicate a useful restructure post-stress effect of EMI of $167 \mathrm{GHz}$ on a morphofunctional renal condition in male rats. At the same time EMI of $144 \mathrm{GHz}$ does not influence a functional morphology of cortical and periencephalic nephron in male rats under stress [53].

Effects of $\mathrm{THz}$ waves on a blood system are to pay particular attention. The experimental results of O.N. Antipova et al. [54-58] display that the 15- and 30-minute exposition of $\mathrm{THz}$ waves of 150.176-150.664 GHz (NO) in animals under acute immobilization stress causes a total normalization of a blood viscosity under different rates-of-shear. The results analyze of blood rheological properties in animals under prolonged stress showed the normalization of a blood viscosity properties under low and high rates-of-shear.

It had been established that a normalization of an intravascular microcirculation component at $\mathrm{THz}$ waves of $150.176-150.664 \mathrm{GHz}$ in male rats under acute and prolonged immobilization stress is correlated with a decrease of high erythrocytes aggregation and caused by recovery of their receptor apparatus activity. Under the given exposure there is a normalization of $\beta$-D-galactose in a carbohydrate component and a recovery of a glycoprotein erythrocyte receptors in male rats under acute and prolonged immobilization stress $[59,60]$.

O.I. Pomoshnikova [61] had found out that $\mathrm{THz}$ waves of $150.176-150.664 \mathrm{GHz}$ partially or totally normalize intravascular 
microcirculation component after stress by recovery of quantitative and qualitative erythrocyte components depending on a regime and time mode. The author considers that 15 -minute time mode of irradiation is the most effective in normalization of quantitative and qualitative erythrocyte components. A daily 30minute irradiation on animals under prolonged immobilization stress normalizes an average hemoglobulin concentration in erythrocytes and their average size and aggregability [59].

It had been showed that EMI of THz band of MEAS of 150.176$150.664 \mathrm{GHz}$ of NO can normalize thrombocyte functional activity in white male rats under acute immobilization stress [62, 63]. Under the given exposure there is a normalization of thrombocyte receptor apparatus activity, this stimulates a recovery of intravascular microcirculation component in male rats under acute immobilization stress $[64,65]$.

S.V. Sukhova et al. [66] had studied EMI of THz of $129.0 \mathrm{GHz}$ atmospheric oxygen effect on a thrombocyte functional activity in male rats under immobilization stress. It had been indicated that in a 5-minute $129.0 \mathrm{GHz} \mathrm{THz}$ irradiation there was a normalization of thrombocyte functional activity in male rats on the background of immobilization stress.

The authors consider that there are mediators of EMI of $\mathrm{THz}$ band in cells and biological fluids are active forms of oxygen (AFO) which are, probably, formed enzymatically by change in protein molecules hydration and increase of cyclooxygenase and xanthine oxidase activity [67]. AFO stimulates a soluble guanylate cyclase by $\mathrm{Ca}^{2+}$, this causes a high concentration of cyclic guanosine monophosphate (cGMP) in endothelial vessels cells and an increase of NO-synthase activity which increases NO producing [67]. This can be one of mechanisms of antiaggregate and antistress effects of $\mathrm{THz}$ waves of MEAS of $129.0 \mathrm{GHz}$ atmospheric oxygen [66].

Today we have information about a significant effect of $\mathrm{THz}$ waves on clotting and fibrinolysis. So it had been showed that under the persistent exposure of MEAS of $150.176-150.664 \mathrm{GHz}$ (on the background of acute immobilization stress) there was a normalization of pro-coagulant, anticoagulant and fibrinolytic activity in blood of rats. It had been established that the most effective time mode was a 30-minute irradiation. It was revealed that a proximate irradiation of animals before the stressor action in a persistent mode prevents the developing of defects in different phases of clotting and fibrinolysis. A divided irradiation mode of animals causes a total normalization of coagulant component in a hemostasis system and fibrinolysis - at a 15minute $\mathrm{THz}$ irradiation of MEAS of $150.176-150.664 \mathrm{GHz}$ of NO. It means that an efficiency of $\mathrm{THz}$ waves on a hemostasis system at a whole organism conditions is determined not only by an exposition, but an irradiation regime [68-70].

Besides, it had been established that THz waves of MEAS of 150.176-150.664 GHz corrects effectively not only acute, but also prolonged defects in a hemostasis system. A daily proximate $30-$ minute irradiation of animals at a chronic immobilization stress condition totally prevents failures in clotting systems and fibrinolysis [71-73]. THz waves of MEAS of $129.0 \mathrm{GHz}$ atmospheric oxygen can stimulate a normalization of clotting, anticoagulant and fibrinolytic activity in blood of rats under immobilization stress. The effect of $\mathrm{THz}$ waves of this band, as well as the NO band, on parameters of a clotting component of hemostasis system (activated partial thromboplastin time, prothrombin time, international normalized ratio, fibrinogen concentration, thrombin time value, factor XII activity in blood plasma depends on an exposition time). It had been fixed that a 5 -minute exposition does not cause change in defected parameters of clotting, a 15-minute exposition leads to a partial normalization, a 30-minute exposition leads to a total normalization of clotting activity in rats' blood at experimental stress-reaction [74]. Analogical changes had been noticed by the authors during the study of fibrinolytic activity. It is showed that the most evident normalization of Hagemankallikrein-dependent fibrinolysis, and plasminogen reserve index in white rats under acute immobilization stress, is noted at a 30minute exposition of electromagnetic waves of MEAS of $129.0 \mathrm{GHz}$ atmospheric oxygen [74].

The presented data display a significant effect of $\mathrm{THz}$ waves on parameters of intravascular microcirculation component: hemostasis system and blood rheology components. There had also been described several effects of $\mathrm{THz}$ waves on a cardiovascular system. In particular it had been showed a normalizing effect of $150.176-150.664 \mathrm{GHz}$ frequency in rats (under acute immobilization stress) on parameters of hemodynamics in abdominal aorta part and femoral artery [7577].

Besides, $\mathrm{THz}$ waves of $\mathrm{NO}$ frequency have a normalizing effect on microvasculature refusion in male rats under acute and prolonged immobilization stress [78-81]. Realization of hemodynamic effects of $\mathrm{THz}$ waves of $150.176-150.664 \mathrm{GHz}$ of NO in male rats under acute and prolonged immobilization stress is performed by an effect on paracrine regulatory mechanisms of vascular endothelium. $\mathrm{THz}$ waves of the given frequencies cause an increase of NO producing by vascular endothelium, which is accompanied by a normalization of a decreased basic and induced vasodilating potency in animals under acute immobilization stress [82]. The exposition course in animals under prolonged stress causes an increase of nitrites concentration - NO stable metabolites [83] and a decrease of endothelin I concentration [84] in blood serum, leading to recovery of vasodilator substances balance - prevents endothelial dysfunction progress. Mechanism of $\mathrm{THz}$ waves of the given band is realized by the NO-synthase component cycle of NO. THz waves do not realize its positive effect on a hemodynamics in magistral arteries and microcirculatory vessels in rats under acute immobilization stress at the NOsynthase blockade $[85,86]$.

Thus, THz waves can change morpho-functional condition of tissues and organs, which influences on a functional organism state in the whole. The literature data indicate that strong regulating properties of many processes in an organism are typical to electromagnetic waves of the given band. Realization of biological effects of $\mathrm{THz}$ band electromagnetic waves is performed at a molecular, subcellular, cellular, organ and organismic levels.

Conflict of interest: none declared.

\section{Reference}

1. Shein AG, Markovskaia AA. Cell and electromagnetic irradiation. Millimeter Waves in Bbiology and Medicine 2010; (4): 5-25. [Article in Russian]

2. Zeni O, Gallerano GP, Perrotta A, Romanò M, Sannino A, Sarti M, et. al. Cytogenetic observations in human peripheral blood leukocytes following in vitro exposure to $\mathrm{THz}$ radiation: a pilot study. Health Phys 2007; 92(4): 349-57. (doi: 10.1097/01.HP.0000251248.23991.35) (PMID: 17351499) 
3. Funk RHW, Monsees T, Ozkucur N. Electromagnetic effects - from cell biology to medicine. Progress in Histochemistry 2009; 43(4): 177-264. (PMID: 19167986) (doi: 10.1016/j.proghi.2008.07.001)

4. Blanka M, Goodmanb R. Electromagnetic fields stress living cells. Pathophisiology 2010; 16(2-3): 71-78. (PMID: 19268550) (doi: 10.1016/j.pathophys.2009.01.006)

5. Cifra M, Fields JZ, Farhadi A. Electromagnetic cellular interactions. Prog Biophys Mol Biol 2011; 105(3): 223-246. (PMID: 20674588) (doi: 10.1016/j.pbiomolbio.2010.07.003)

6. Kazarinov KD. Biological effects of electromagnetic field of $\mathrm{THz}$ band. Electronic technology. Series 1: Microwave technology 2009; 503(4): 48-58. [Article in Russian]

7. Kulshpanov TN. Generation and THz irradiation usage: history and perspectives. Novosibirsk State University Reporter: Physics 2010; 5(4): 24-27. [Article in Russian]

8. Chekrygin VE. THz band is a health guard. News of South federal university: Technical science 2009; 96(7): 102-107. [Article in Russian]

9. Betsky OV, Lebedeva NN. Modern ideas of low-intensity millimeter waves mechanism effects on biological objects. Millimeter Waves in Biology and Medicine 2001; (3): 5-19. [Article in Russian]

10. Olrando RA, Gallerano GP. Teraherz Radiation Effects and Biological Applications. Journal of Infrared, Millimeter and Teraherz Waves 2009; 30(12): 1308-1318.

11. Betsky OV, Krenitsky AP, Maiborodin AV, et al. Molecular HITRANspectra of metabolites gas in $\mathrm{THz}$ and IR bands, and their usage in biomedical technologies. Biomedical Radioelectronics 2007; (7): 5-9. [Article in Russian]

12. Rothman LS, Barbe A, Benner CD, Brown LR, Camy-Peyret C, Carleer $\mathrm{MR}$, et al. The HITRAN molecular spectroscopic database: edition of 2000 including updates through 2001. Journal of Quantitative Spectroscopy \& Radiative Transfer 2003; 82: 5-44. (doi: 10.1016/S0022-4073(03)00146-8)

13. Gulyayev YV, Krenitsky AP, Betsky OV, Mayborodin AV, Kirichyuk VF. Terahertz techniques and its application in biomedical technologies. Achievements of Modern Radioelectronics 2008; (9): 8-16. [Article in Russian]

14. Cherkasova OP, Fedorov VI, Nemova EF, Pogodin AS. Influence of terahertz laser radiation on the spectral characteristics and functional properties of albumin. Optics and Spectroscopy 2009; 107(4): 534-537. (doi: 10.1134/S0030400X09100063)

15. Fedorov VI. Study of biological effects of electromagnetic radiation of submillimeter part of terahertz range. Biomedical Radioelectronics 2011; (2): 17-27. [Article in Russian]

16. Cherkasova OP, Fedorov VI, Nemova EF, Popova SS, Pogodin AS, Khamoyan AG. Teraherz radiation influence on peptide conformation $P$ roc. Proc SPIE 6727, ICONO 2007: Nonlinear Laser Spectroscopy and High-Precision Measurements; and Fundamentals of Laser Chemistry and Biophotonics, 672721 (July 09, 2007). (doi: 10.1117/12.752431)

17. Kapralova A V, Pogodin AS. Influence of teraherz radiation of various rangs on molecule's conformation of bovine serum albumin. In: Digest Reports of International Symposium "Teraherz Radiation: Generation and Application". Novosibirsk, Russia, 2010. [Text in Russian]

18. Nemova EF, Fedorov VI. The study of $\mathrm{THz}$ irradiation effect on conformational change in the structure of serum bull albumin by the spin pathfinder. Novosibirsk State University Reporter: Physics 2010; 5(4): 173-176. [Article in Russian]

19. Pronina EA, Shub GM, Krenitskij AP, Majborodin AV, Betskij OV, Gulyaev JuV. The influence of electro-magnetic radiation on the frequency of atmospheric oxygen absorption and radiation molecular spectrum on the activity of bacteria antioxidase protection enzymes. Biomedical Radioelectronics 2009; (8): 57-63. [Article in Russian]

20. Pronina EA, Shub GM, Shvidenko IG. Electromagnetic radiation influence with molecular spectrum absorption and nitric oxide radiation frequency on superoxide dismutase bacteria activity. Saratov
Journal of Medical Scientific Research 2009; 5(2): 164-166. [Article in Russian]

21. Pronina EA, Shub GM, Shvidenko IG. Changing of bacteria catalase activity under the influence of electro-magnetic radiation on a frequency of nitric oxide absorption and radiation molecular spectrum. Saratov Journal of Medical Scientific Research 2009; 5(3): 321-323. [Article in Russian]

22. Kirichuk VF, Tsymbal AA. Effects of terahertz irradiation at nitric oxide frequencies on intensity of lipoperoxidation and antioxidant properties of the blood under stress conditions. Bull Exp Biol Med 2009; 147(8): 166-170. (doi: 10.1007/s10517-009-0669-x)

23. Homenko A, Kapilevich B, Kornstein R, Firer MA. Effects of $100 \mathrm{GHz}$ radiation on alkaline phosphatase activity and antigen-antibody interaction. Bioelectromagnetics 2009; 30(3): 167-175. (PMID: 19051324) (doi: 10.1002/bem.20466)

24. Fyodorov VI, Clementyev VM, Hamoian AG, et al. Submillimeter laser as a potential instrument of medical diagnostics. Millimeter waves in biology and medicine 2009; (1-2): 88-97. [Article in Russian]

25. Ol'shevskaia luS., Kozlov AS, Petrov AK, et al. Effect of terahertz (submillimeter) laser radiation on cell membrane permeability. Novosibirsk state university reporter: Physics 2010; 5(4): 177-181. [Article in Russian]

26. Ramundo-Orlando A, Gallerano GP, Stano P, Doria A, Giovenale E, Messina G, et. al. Parmeability changes induced by $130 \mathrm{GHz}$ pulsed radiation on cationic liposomes loaded with carbonic anhydrase. Bioelectromagnetics 2007; 28: 587-598. (doi: 10.1002/bem.20343) (PMID: 17620303)

27. Kirichuk VF., Volin MV., Krenitsky AP, et al. Thrombocytes in hemostasis system reaction on THF exposure. Saratov State Medical University Publ., Saratov, Russia, 2002. [Book in Russian]

28. Kirichuk VF, Malinova Al, Krenitsky AP, et al. Hemorheology and electromagnetic EHF band irradiaton. Saratov State Medical University Publ., Saratov, Russia, 2003. [Book in Russian]

29. Raikova SV, Pronina EL, Shub GM. Effect of electromagnetic $\mathrm{THz}$ radiation of nitrogen oxide frequency on phagocytic activity of peritoneal macrophages in white mice. Immunology 2009; 30(5): 270272. [Article in Russian]

30. Kirichuk VF, Andronov EV, Mamontova NV, et al. Effect of $\mathrm{THz}$ radiation of nitrogen oxide frequency in crossed magnetic and electric fields on blood rheological properties, in the patients with unstable angina. Biomedical Radioelectronics 2005; (3): 34-38. [Article in Russian]

31. Krenitsky AP, Maiborodin AV, Tupikin VD, Kirichuk VF, Andronov EV, Betsky OV. Electrodynamical model of $\mathrm{THz}$ waves and atmospheric oxygen interaction with biomedium in crossed magnetic and electric fields. Biomedical Radioelectronics 2004; (11): 35-45. [Article in Russian]

32. Andronov EV, Kirichuk VF. EMR of THZ range at the nitric oxide frequence $400 \mathrm{GHz}$ as factor for correction of platelet aggregation in patients with unstable agina in vitro. Saratov Journal of Medical Scientific Research 2006; 2(1): 22-27. [Article in Russian]

33. Olshevskaia JS, Kozlov AS, Petrov LK, et al. Effect of THz (submillimeter) laser radiation on neurons at in vitro conditions. I.P. Pavlov Journal of Higher Nervous Activity (Zh Vyssh Nerv Deiat I P Pavlova) 2009; 59(3): 353-359. [Article in Russian]

34. Olshevskaya JS, Ratushnyak AS, Petrov AK, Kozlov AS, Zapara TA. Effect on teraherz electromagnetic waves on neurons systems. In: Proceedings 2008 IEEE Region 8 international conference on computational technologies in electrical and electronics engineering "SIBIRCON 2008", 2008: 210-211. (doi: 10.1109/SIBIRCON.2008.4602607)

35. Ratushnyak AS, Zapara TA, Ryabchikova EI, et al. Influence of submillimeter range electromagnetic radiation on neuron systems. In: The Third International Symposium on Modern Problems of Laser Physics. Novosibirsk, Russia, 2000. [Article in Russian] 
36. Kirichuk VF, Andronov EV, Efimova NV, Krenickiy AP, Mayborodin AV, Rytic AP, Kiriyasi AV. Influence of theragertz irradiation of eleveted capacity on platelet aggregation and behavioral reactions of white blood. Biomedical Radioelectronics 2009; (12): 66-71. [Article in Russian]

37. Kirichuk VF, Efimova NV, Andronov EV. Effect of high power terahertz irradiation on platelet aggregation and behavioral reactions of albino rats. Bull Exp Biol Med 2009; 148(5): 746-749. (PMID: 20396783)

38. Tunikin VD. Changes in renal tissues at stress and electromagnetic radiation of various $\mathrm{GHz}$ bands. Saransk, Russia, 2011. [Book in Russian]

39. Bondar NP, Kovalenko IL, Avgustinovich DF, Khamoyan AG, Kudryavtseva NN. Behavioral effect of terahertz waves in male mice. Bull Exp Biol Med 2008; 145(4): 401-405. (doi: 10.1007/s10517-0080102-x)

40. Kirichuk VF, Tsymbal AA. Use of terahertz electromagnetic radiation at nitric oxide frequencies for the correction of thyroid functional state during stress. Vestn Ross Akad Med Nauk (Annals of the Russian Academy of Medical Sciences) 2010; (4): 37-40. (PMID: 20540354)

41. Tsymbal AA, Kirichuk VF, Kurtukova MO. Influence of chronic stress and terahertz radiation at nitric oxide frequency on functional activity of thyroid gland. Saratov Journal of Medical Scientific Research 2010; 6(4): 767-771. [Article in Russian]

42. Polina JuV, Rodzaevskaya EB, Naumova LI. Cortizol level and adrenal gland morphology under influence of low-intensity electro-magnetic waves and under stress. Saratov Journal of Medical Scientific Research 2008; 4(1): 127-130. [Article in Russian]

43. Tsymbal AA, Kirichuk VF, Antipov ON, Kurturova MO, Andronov EV. Changes in the level of corticosterone in the blood of experimental animals exposed to terahertz waves at a frequency of atmospheric oxygen $129.0 \mathrm{GHz}$ on a background of acute and prolonged stress. Biomedical Radioelectronics 2011; (8): 23-28. [Article in Russian]

44. Tsymbal AA. Changes in a corticosterone level in blood of animals at an exposure of $\mathrm{THz}$ waves of an atmospheric oxygen at the normal and stress condition. In: Items of physical biomedicine. Saratov State Medical University Publ., Saratov, Russia, 2011: 319-321. [Text in Russian]

45. Kirichuk VF, Ivanov AN, Tsymbal AA, Andronov EV. Realization mechanism of physiological effects of $\mathrm{THz}$ waves of NO frequencies. Millimeter Waves in Biology and Medicine 2009; (3): 58-65. [Article in Russian]

46. Tsymbal AA, Kirichuk VF, Krenitsky AP, Betsky OV. Restoration of the main indicators of the metabolic status of terahertz waves at frequencies of nitric oxide $150.176 \ldots 150.664 \mathrm{GHz}$ in the experiment. Biomedical Radioelectronics 2011; (1): 30-35. [Article in Russian]

47. Tsymbal AA. Changes in protein spectrum of blood, the activity of glutathione-S-transferase, glucose and ceruloplasmin under the influence of terahertz waves at frequencies of nitric oxide $150.176 \ldots 150.664 \mathrm{GHz}$ with acute stress. Biomedical Radioelectronics 2011; (8): 30-35. [Article in Russian]

48. Samhan-Arias AK, Tyurina YY, Kagan VE. Lipid antioxidants free radical scavenging versus regulation of enzymatic lipid peroxidation. J Clin Biochem Nutr 2011; 48(1): 91-95. (PMID: 21297919) (PMCID: PMC3022072) (doi: 10.3164/jcbn.11-009FR)

49. Kirichuk VF, Tsymbal AA. Effects of terahertz irradiation at nitric oxide frequencies on intensity of lipoperoxidation and antioxidant properties of the blood under stress conditions. Bull Exp Biol Med 2009; 148(2): 200-203. (PMID: 20027328)

50. Kirichuk VF, Tsymbal AA. Peculiarities of the effect of terahertz radiation at nitric oxide frequencies on gaseous and electrolyte composition of the blood in different types of stress. Bull Exp Biol Med 2010; 150(2): 191-194. (PMID: 21240370)

51. Tsymbal AA, Kirichuk VF, Antipova ON, Andronov EV, Krenitsky AP. The dynamics of blood oxygenation in experimental animals exposed to terahertz waves at frequencies of nitric oxide in stress. Biomedical Radioelectronics 2011; (1): 36-39. [Article in Russian]
52. Kirichuk VF, Kireev SI, Bogomolova NV, Dulatov RM, Krenitsky AP. Assessment of the effectiveness of THz-therapy-NO in the complex treatment of patients with deforming arthrosis (clinical and experimental investigation). Biomedical Radioelectronics 2011; (1): 5861. [Article in Russia]

53. Rodzaevskaia EB, Bugaeva IO, Uvarova IA, et al. Histofunctional condition of renal parenchyma at stress and experiment. In: Macroand micromorphology: interacademic reporter. Saratov, Russia, 2011: 202-212. [Text in Russian]

54. Kirichuk VF, Antipova ON, Ivanov AN, et al. Antistress effect of electromagnetic radiation of nitrogen oxide terahertz frequency. Biomedical Radioelectronics 2004; (11): 12-20. [Article in Russian]

55. Kirichuk VF, Antipova ON, Andronov EV, Ivanov AN, Kreniskiy AP, Mayborodin AV. Efficiency of the different modes THz-radiation waves on restoration of rheology propereties of the blood under stressreaction with white rats. Biomedical Radioelectronics 2009; (6): 55-62. [Article in Russian]

56. Kirichuk VF, Tomina IA, Aitipova ON. Effect of electromagnetic waves of nitrogen oxide frequency on hemorheology change under an acute stress. In: Items of physical biomedicine: regional international edited volume. Saratov State Medical University Publ., Saratov, Russia, 2011: 289-296. [Text in Russian]

57. Kirichuk VF, Antipova ON, Tomina JA, Smyshlyaeva IV, Andronov EV, Tsymbal AA, Krenitsky AP. Comparative effectiveness of the preventive effects of the waves of the terahertz frequency band of nitric oxide on the rheological properties of blood of albino rats under acute stress. Biomedical Radioelectronics 2011; (8): 36-42. [Article in Russian]

58. Kirichuk VF, Antipova ON, Andronov EV, Ivanov AN, Krenickiy AP, Majborodin AV. Experimental Substantiation of Efficiency of Preliminary Application Influence of Theragertz Waves at Nitric Oxide Frequencies on Broken Rheological Properties of Blood. Biomedical Radioelectronics 2011; (3): 40-46. [Article in Russian]

59. Kirichuk VF, Ivanov AN, Andronov EV, Svistunov SV. Correction of a carbohydrate component of glycoprotein erythrocyte receptors with the use of EMI of nitrogen oxide THF. In: Items of pathogenesis in typical pathological processes: Materials of the II Russian international conferention. Novosibirsk, Russia, 2010: 162-165. [Text in Russian]

60. Kirichuk VF, Svistunov SV, Andronov EV, Ivanov AN. Stress depended changes in activityof gp red blood cells receptors and its correction by therahertz waves at nitric oxide frequency. Saratov Journal of Medical Scientific Research 2011; 7(3): 583-587. [Article in Russian]

61. Kirichuk VF, Pomoshnikova OI, Antipova ON, et al. The influence of electromagnetic radiation in the terahertz frequency range of molecular emission and absorption of nitric oxide on the recovery of quantitative and qualitative composition of red blood cells (in vivo). Biomedical Radioelectronics 2004; (11): 21-27. [Article in Russian]

62. Kirichuk VF, Antipova ON, Ivanov AN, et al. Teraherz Waves Eleminate the Disturbances of Microcirculation System. In: The Joint 30th International Conference Teraherz Electronics. Williamsburg, Virginia, USA, 2005: 5-10.

63. Ivanov AN. Thrombocytes reaction on electromagnetic radiation of NO molecular emission and absorption spectrum. Thrombosis, hemostasis and rheology 2006; (3): 51-57. [Article in Russian]

64. Kirichuk VF, Ivanov AN, Andronov EV, Svistunov SV, Krenitskij AP, Majborodin AV. Influence of electromagnetic theragertz radiation at the range of nitric oxide frequencies on poststressor infringements of structure in carbohydrate component and activity of platelet glycoprotein receptors. Biomedical Radioelectronics 2010; (5): 39-46. [Article in Russian]

65. Kirichuk VF, Andronov EV, Ivanov AN, Svistunov SV. Correction of stress-depended changes of glucoproteid platelet receptors activity by electromagnetic radiation of terahertz range. Saratov Journal of Medical Scientific Research 2010; 6(3): 511-515. [Article in Russian]

66. Suhova SV, Ivanov AN, Corableva TS, et al. Effects of 150.176-150.664 $\mathrm{GHz} \mathrm{NO}$ molecular emission and absorption spectrum and $129.0 \mathrm{GHz}$ oxygen on microvasculature component of a hemostasis system. In: Materials of the $68^{\text {th }}$ practical-scientific conference of students and 
young specialists of Saratov State Medical University. Saratov, Russia, 2007: 141-142. [Text in Russian]

67. Potcelueva MM, Pustovidko AV, Evtodienko luV. Appearing of reactive oxygen forms in water solutions under the exposure of EMI of EHF band. Abstracts of Science Academy 1998; (3): 415-418. [Article in Russian]

68. Kirichuk VF, Cymbal AA, Antipova ON, et al. Coagulation hemostasis, fibrinolysis system and Terahertz therapy in acute experimental stress. Millimeter Waves in Biology and Medicine 2006; (3): 29-39. [Article in Russian]

69. Kirichuk VF, Tsymbal AA, Antipova ON, Tupikin VD, Maiborodin AV, Krenitskii AP, Betskii OV. Correction of acute stress-induced disorders of hemostasis using the KVCh-NO apparatus. Biomedical Engineering 2006; 40(1): 33-37. (doi:10.1007/s10527-006-0035-5)

70. Tsymbal AA. The origin of change in defected clotting and fibrinolytic blood properties under the exposure of THz waves of NO 150.176150.664 GHz. Author's abstract on PhD degree in Medicine. Saratov State Medical University, Saratov, Russia, 2007. [Text in Russian]

71. Kirichuk VF, Tsymbal AA, Antipova ON, Tupikin VD, Maĭborodin AV, Krenitsky AP, Betsky OV. Coagulation hemostasis and fibrinolytic potential of blood in conditions of chronic stress and terahertz therapy. Ross Fiziol Zh Im I M Sechenova (Russian Journal of Physiology) 2007; 93(1): 46-54. (PMID: 17465273) [Article in Russian]

72. Kirichuk VF, Cymbal AA, Andronov EV, Antipova ON, et al. Pathology of blood coagulation, fibrinolysis under conditions of chronic stress and terahertz therapy. Millimeter Waves in Biology and Medicine 2006; (3): 40-50. [Article in Russian]

73. Kirichuk VF Tsymbal AA, Aiatipova ON, et al. Pathology of coagulative component in a hemostasis system, fibrinolytic blood potential at a chronic stress condition and $\mathrm{THz}$ therapy. Biomedical Radioelectronics 2006; (8-9): 14-22. [Article in Russian]

74. Kirichuk VF, Tsymbal AA, Kreniskiy AP, Mayborodin AV. Theragerz radiations application on frequency of atmospheric oxygen of 129.0 $\mathrm{GHz}$ for correction coagulation hemostasis and fibrinolysis frustrations. Biomedical Radioelectronics 2009; (9): 11-17. [Article in Russian]

75. Kirichuck VF, Velikanova TS, Ivanov AN. Influence THZ radiation at the nitric oxide freguence on poststressor infringenets of hemodynamics parameters of blood in white rats. Regional Haemodynamics and Microcirculation 2010; 9(3): 70-76. [Article in Russian]

76. Kirichuck VF, Velikanova TS, Ivanov AN. Hemodynamic Changes Induced by Preventive Exposure to Terahertz Radiation at a Frequency Range Corresponding to Molecular Emission and Absorption Spectrum of Nitric Oxide in Animals under Conditions of Acute Stress. Bull Exp Biol Med 2010; 151(2): 186-189. (PMID: 22238746) (doi: 10.1007/s10517-011-1285-0)

77. Kirichuck VF, Velikanova TS, Ivanov AN. Influence thz radiation at the nitric oxide freguence on poststressor infringenets of hemodynamics parameteres of blood in white rats. Fundamental Research 2011; (3): 77-82. [Article in Russian]

78. Kirichuck VF, Ivanov AN, Kiriyazi TS, Krenickiy AP, Mayborodin AV Changing the functional state of the endothelium and peripheral perfusion under the influence of electromagnetic waves in the terahertz range of frequencies nitric oxide white rats in a state of acute immobilization stress. Biomedical Radioelectronics 2010; (12): 30-37. [Article in Russian]

79. Kirichuk VF, Ivanov AN, Kirijazi TS. Correction of Microcirculatory Disturbances with Terahertz Electromagnetic Radiation at Nitric Oxide Frequencies in Albino Rats under Conditions of Acute Stress. Bull Exp Biol Med 2011; 151(3): 288-291. (doi:10.1007/s10517-011-1311-2).

80. Kirichuck VF, Ivanov AN, Kiriyazi TS. Changes of peripheral perfusion in white rats in a state of acute immobilization stress under the influence of electromagnetic waves of teraheertz range at nitric oxide frequency. Fundamental Research 2011; (5): 78-83. [Article in Russian]

81. Kirichuck VF, Ivanov AN, Kiriyazi TS, Krenitsky AP. Use of the Orbita apparatus for correction of prolonged disorders of tissue perfusion.
Biomedical Engineering 2011; 45(3): 110-113. (doi: 10.1007/s10527011-9222-0)

82. Kirichuck VF, Kiriyazi TS, Ivanov AN. The influence of terahertz electromagnetic waves at the frequency of nitric oxide on endothelial funcyion in white rats in a state of acute immobilization stress. Fundamental Research 2011; (2): 78-82. [Article in Russian]

83. Kirichuck VF, Ivanov AN, Kulapina EG, Krenickiy AP, Mayborodin AV. Effect of Terahertz Electromagnetic Irradiation at Nitric Oxide Frequencies on Concentration of Nitrites in Blood Serum of Albino Rats under Conditions of Immobilization Stress. Bull Exp Biol Med 2011; 149(2): 174-176. (PMID: 21113484) (doi: 10.1007/s10517-010-0900-9)

84. Ivanov AN, Kirichuk VF, Kurtukova MO, Bogomolova NV, Andronov EV. Influence of terahertz range radiation at the frequencies of molecular spectrum of nitric oxide $150 \pm 0.75 \mathrm{GHz}$ on changes of production and mechanisms of regulation of endotelin i in white mail rats, in a state of acute and prolonged stress. Bulletin of New Medical Technologies 2009; 16(4): 19-21. [Article in Russian]

85. Kirichuk VF, Ivanov AN, Velikanova TS, Andronov EV, Smyshlyaeva IV, Kurtukova MO, Krenitsky AP. Influence of endothelial NO shyntase inhibitor L-NAME and influence of electromagnetic theraherte waves at frequenciy of a molecular spectrum of radiation and absorption of nitric oxide $150.176 \ldots 150.664 \mathrm{GHz}$ on system hemodynimic in mail rats subjected in conditions of immobilization stress. Biomedical Radioelectronics 2011; (1): 19-24. [Article in Russian]

86. Kirichuk VF, Ivanov AN, Kiriyazi TS, Andronov EV, Babichenko NE, Smyshlyaeva IV, Sakhan MA. The role of NO-synthase in the reaction of the endothelium and changes in peripheral perfusion under the influence of electromagnetic terahertz waves at frequencies of nitric oxide in albino rats in a state of acute stress. Biomedical Radioelectronics 2011; (8): 12-17. [Article in Russian]

\section{Authors:}

Vyacheslav F. Kirichuk - MD, D.Sc. Professor, Honored Scientist of Russia, Head of Department of Normal Physiology n.a. I.A. Chuevsky, Saratov State Medical University n.a. V.I. Razumovsky, Saratov, Russia;

Alexey N. Ivanov - MD, PhD, Associate Professor, Department of Normal Physiology n.a. I.A. Chuevsky, Saratov State Medical University n.a. V.I. Razumovsky, Saratov, Russia. 